Chirurgia (2021) 116: 678-688

No. 6, November - December

Copyright@ Celsius

http://dx.doi.org/10.21614/chirurgia.116.6.678

\title{
Definitive Surgery for Liver Trauma in a Tertiary HPB Center (with video)
}

\author{
Alexandru Barcu ${ }^{1,2 \sharp}$, Bianca Mitricof ${ }^{2 \sharp}$, Cosmin Verdea ${ }^{1}$, Laura Bălănescu ${ }^{3}$, Dana Tomescu ${ }^{4}$, Gabriela Droc ${ }^{4}$, \\ Ioana Lupescu ${ }^{5}$, Doina Hrehoreț ${ }^{1}$, Vladislav Brașoveanu ${ }^{1,6}$, Irinel Popescu ${ }^{1,6}$, Florin Botea ${ }^{1,6 * *}$ \\ ${ }^{1}$ Center of General Surgery and Liver Transplantation, Fundeni Clinical Institute, Bucharest, Romania \\ ${ }^{2}$ Medical Doctoral School, IOSUD "Titu Maiorescu" University of Bucharest, Romania \\ ${ }^{3}$ Clinical Emergency Hospital for Children Grigore Alexandrescu, Bucharest, Romania \\ ${ }^{4}$ Center of Anesthesia and Intensive Care, Fundeni Clinical Institute, Bucharest, Romania; \\ ${ }^{5}$ Center of Diagnostic and Interventional Radiology, Fundeni Clinical Institute, Bucharest, Romania \\ ${ }^{6}$ Faculty of Medicine, University "Titu Maiorescu", Bucharest, Romania
}

*Corresponding author:

Florin Botea, MD

Center of General Surgery and Liver

Transplantation

Fundeni Clinical Institute

Soseaua Fundeni 258, Bucharest

Romania, 022328

E-mail: florinbotea@gmail.com

\#Authors with equal contribution

\section{Rezumat}

Tratamentul chirurgical definitiv pentru traumatisme hepatice într-un centru terțiar $\mathrm{HPB}$

Introducere: Chirurgia în traumatismele hepatice severe rămâne o provocare chiar şi pentru chirurgii HPB, în principal din cauza instabilității hemodinamice a pacienților, a implicării elementelor vasculare şi biliare majore, a calității parenchimului hepatic şi a variantelor anatomice frecvente. În acest context, în ciuda politicii conservatoare, rezecția hepatică majoră este încă necesară în cazuri selecționate. De asemenea, poate fi necesar transplantul hepatic ca ultimă măsură terapeutică. Studiul nostru îşi propune să analizeze rezultatele tratamentului chirurgical definitiv pentru traumatismele hepatice (TH) într-un centru terțiar HBP.

Metode: Şaizeci şi şase de pacienți cu TH au fost internați şi tratați în centrul nostru între iunie 2000 şi iunie 2021. Vârsta medie a fost de 29 de ani (media 35, interval 10-76). Raportul bărbați/femei a fost de 50/16. Conform sistemului American Association for the Surgery of Trauma (AAST), TH au fost de gradul II la un pacient (1,5\%), gradul III la 11 pacienți (16,7\%), gradul IV la 25 de pacienți $(37,9 \%)$ şi gradul V în 29 puncte $(43,9 \%)$; niciun pacient nu a avut TH de gradul I sau VI.

Rezultate: Cincizeci şi doi de pacienți $(78,8 \%)$ au beneficiat de intervenție chirurgicală şi 14 pacienți $(21,2 \%)$ de tratament nonoperator (TN). Packing-ul perihepatic a fost efectuat anterior la 38 
pacienți (73,1\%). Chirurgia a constat în rezectii hepatice $(\mathrm{RH})$ la 51 de pacienti $(77,3 \%)$ şi transplant de ficat la un pacient (1,5\%). Rata de $\mathrm{RH}$ majore a fost de 51,9\% (27 HR). Ratele generale morbiditate majoră şi mortalitate au fost de 33,3\% (20 pacienți) şi, respectiv, de 13,6\% (9 pacienți). Pentru intervențiile chirurgicale, rata complicaților majore a fost de 35,3\% (18 pacienți), în timp ce pentru RH majoră şi minoră a fost de 40,7\% (11 pacienți) şi, respectiv, 29,2\% (7 pacienți); rata de mortalitate a fost de $15,7 \%$ (8 pacienți). După TN, ratele majore de morbiditate şi mortalitate au fost de $14,3 \%$ (2 pacienți) şi, respectiv, 7,1\% (1 pacient).

Concluzii: Rezecțiile hepatice, în special cele majore şi/sau care implică reconstrucții vasculare şi biliare, precum şi tratamentul nonoperator al leziunilor hepatice severe sunt optim efectuate în centrele de HBP terțiare, reducând astfel ratele de morbiditate şi mortalitate, având în acelaşi timp transplantul hepatic ca ultimă opțiune terapeutică.

Cuvinte cheie: traumatism hepatic, leziuni hepatice de grad înalt, rezecție hepatică majoră, tratament neoperator, centru terțiar HBP

\begin{abstract}
Background: Surgery for severe liver trauma remains challenging even for HPB surgeons, mainly due the hemodynamical instability, involvement of major vascular and biliary elements, impaired background liver and frequent anatomical variants. In this setting, despite conservative policy, major liver resection is still required in selected cases. Also salvage liver transplantation may be needed. Our study aims to analyze the results after definitive surgery for hepatic injury (HI) in a tertiary HPB center.

Methods: Sixty-six patients with HI were admitted and treated in our center between June 2000 and June 2021. The median age was 29 years (mean 35, range 10-76). The male/female ratio was 50/16. According to the American Association for the Surgery of Trauma (AAST) system, HIs were grade II in one patient (1.5\%), grade III in 11 pts (16.7\%), grade IV in 25 pts (37.9\%), and grade V in 29 pts (43.9\%); no patient had grade I or VI HI.

Results: Fifty-two pts (78.8\%) benefitted from surgery and 14 pts (21.2\%) from non-operative treatment (NOT). Perihepatic packing was previously performed in 38 pts (73.1\%). Surgery consisted in hepatic resections (HR) in $51 \mathrm{pts}$ (77.3\%) and liver transplantation in one patient (1.5\%). The rate of major HR was $51.9 \%$ ( $27 \mathrm{HRs})$. The overall major morbidity and mortality rates were $33.3 \%$ (20 pts) and $13.6 \%$ (9 pts), respectively. For surgery, the major complication rate was $35.3 \%$ (18 pts), while for major and minor HR were 40.7\% (11 pts) and 29.2\% (7 pts), respectively; the mortality rate was $15.7 \%$ ( $8 \mathrm{pts})$. After NOT, the major morbidity and mortality rates were $14.3 \%(2 \mathrm{pts})$ and $7.1 \%(1 \mathrm{pt})$, respectively.

Conclusions: Hepatic resections, especially major ones and/or involving vascular and biliary reconstructions, as well as non-operative treatment for severe hepatic injuries, are to be carried out in tertiary HPB centers, thus minimizing the morbidity and mortality rates, while having the liver transplantation as salvage option.
\end{abstract}

Key words: hepatic trauma, high-grade hepatic injuries, major liver resection, non operative treatment, tertiary HPB center

\section{Introduction}

Abdominal trauma can cause significant damage to the abdominal organs, liver trauma representing the most frequent type of injury. In $80 \%$ of the cases, it can be accompanied by injury of other viscus, in which case the morbidity and mortality rates are high (1). 
The liver is most affected by blunt and penetrating traumas. Blunt traumas are mostly caused by car accidents (2), while lesions determined by knives and guns predominate in penetrating traumas. The ratio between liver injuries caused by blunt traumas and those caused by penetrating traumas, differs around the globe. While in the UK, the number of injuries caused by blunt traumas is double compared to the ones from penetrating traumas (3), in South Africa and North America, most of these injuries are the result of penetrating traumas $(66 \%$ in South Africa and 86\% in North America) (4, 5). In Romania, blunt trama is a national health issue, as continues to have the highest incidence among the European countries, with a value of 85/1.000.000 (6). Consequently, treatment of liver trauma remains of utmost importance. Liver trauma, as all traumas, is referred to the closest Emergency Hospital, which, in absence of HPB expertise, refers the patient to a tertiary HPB center. Currently, liver trauma in stable patients is based on non-operative treatment (NOT), consisting in careful monitoring, intensive care support and interventional treatment in a specialized center, thus significantly improving both morbidity and mortality rates (1). However, in unstable patients, surgery for severe HI remains challenging even for HPB surgeons, mainly due the hemodynamical instability, involvement of major vascular and biliary elements, impaired background liver and frequent anatomical variants. In this setting, despite conservative policy, major liver resection is still required in selected cases. Also salvage liver transplantation may be needed. Our study aims to analyze the results after definitive surgery for trauma in a tertiary HPB center.

\section{Materials and Methods}

\section{Study Group}

Sixty-six patients with HI were admitted and treated in our center between June 2000 and
June 2021. The median age was 29 years (mean 35, range 10-76). The male/female ratio was $50 / 16$. HIs were in the right hemiliver in $41 \mathrm{pts}(62.1 \%)$, left hemiliver in $17 \mathrm{pts}(25.8 \%)$, bilobar in 7 pts $(10.6 \%)$, and in segment 1 alone in one patient (1.5\%).

According to the American Association for the Surgery of Trauma (AAST) system, HIs were grade II in one patient (1.5\%), grade III in $11 \mathrm{pts}(16.7 \%)$, grade IV in $25 \mathrm{pts}(37.9 \%)$, and grade V in 29 pts (43.9\%); no patient had grade I or VI HI. Almost all patients had blunt trauma (63 pts, representing 95.5\%), except 3 with stab wound (4.5\%).

Associated traumas were encountered in 22 pts (33.3\%): other abdominal and pelvic structures in $18 \mathrm{pts}(27.3 \%)$, thorax in $17 \mathrm{pts}$ $(25.8 \%)$, head in $7 \mathrm{pts}(10.6 \%)$, and/or limbs or vertebral column in $6 \mathrm{pts}(9.1 \%)$.

\section{Analyzed Data}

Patient demographics, preoperative data (anamnesis, hemodynamic stability, type of hepatic trauma, associated trauma, imaging data), information from surgery (type of HI, surgical technique used, type of hepatic resection, use of Pringle maneuver and/or vascular exclusion, associated surgical procedures, blood loss, blood transfusion requirements, duration of surgery), and postoperative data (90-day complications and mortality) were gathered in a database and analysed.

The primary end-point was the short-term results after major liver resection, based on the postoperative morbidity and mortality. All postoperative complications for 90 days after trauma were recorded and classified according to Dindo-Clavien classification et al (7). At least grade IIIB complications were considered life-threatening and defined as major complications. Complications related with the liver, such as hemoperitoneum, hematoma, abscess, bile leak, and/or liver failure were defined as liver-related complications. Operative mortality was considered death occurring within the 90 postoperative days after trauma. Long-term follow-up was considered not relevant for the study. 


\section{Diagnostic and Treatment}

All patients with HI were evaluated based on anamnesis, clinical exam, vital parameters and its variations, lab tests, imaging (ultrasound, CT scan). Particularly, CT scan was used to classify the HI according to the American Association for the Surgery of Trauma (AAST) system (8). Furthermore, to correlate the HI grade with the hemodynamic status, we also used the classification according to the World Society of Emergency Surgery (WSES) (9).

Patients admitted after being already operated in other centers for temporary haemostasis with liver packing were offered surgery for definitive haemostasis after 48 to 72 hours from the first operation. This period of time was used for completion of diagnosis, medical treatment and careful monitoring.

Patients with HI directly referred to us were evaluated for non-operative treatment (NOT), indicated in case of in case of hemodynamically unstable patient after intensive care support, or in hemodynamically stable patients who presented with peritonitis and/or with associated severe head trauma (10). NOT consisted in careful monitoring, intensive care support, and repeated CT-scans; in selected cases, arterial embolization was used. NOT was considered ineffective and the patient was referred to emergency surgery in case of active bleeding showed at CT scan, and/or massive fluid resuscitation or transfusion of more than 3 units of blood transfusion, or hemodynamic instability despite NOT; any other intraabdominal injury diagnosed during NOT that required surgery $(11,12)$.

Open approach was used in all patients referred to surgery, using a large incision to have the optimal access to the entire liver and its main vessels. Major HR was defined as the removal of at least three segments. All established surgical techniques were deployed: anatomic/non-anatomic, major/minor resections; with/without prior liver mobilization approaches.

Complete and fast liver mobilization was useful. Otherwise, the HI may not be had been accessible, and even may had worsen due to excessive traction for exposure.

Superficial lacerations usually responded to conservative techniques such as manual compression Pringle maneuver, use of cautery, argon beam coagulation, and or energydevices, topical haemostatic agents. Perihepatic packing was used in case of failure of the aforementioned procedures; this could be removed intraoperatively, if haemostasis was obtained, or during the following operation. HIs with deep lacerations and/or avulsions typically required ligation/suture of bleeding vessels, direct liver suturing, and even hepatic resection (debridement or anatomic resection) (13). In case of deep and narrow HI, a balloon tamponade could be used. Autotransfusion was used whenever feasible.

The removal of the perihepatic pack was performed 48-72 hours after the initial operation. When the initial procedure was carried out in other hospital, the patient was transferred only when hemodynamically stable. Otherwise, prior to transfer any active bleeding had to be controlled, even by repacking. The preferred technique for hepatic transection was the clamp crushing method (Kelly-clasia). Vascular control using Pringle maneuver and/or total vascular exclusion was always used to control excessive bleeding. Haemostasis on the hepatic cut surface was performed using the standard method, such as ligatures, sutures, electrocoagulation, and haemostatic agents. In case of necrosis, resectional debridement and even upfront anatomical resection (for extensive necrosis) were performed (14). When HI led to liver failure, liver transplantation was considered.

Grade V HIs involving the vena cava and/or main hepatic veins were challenging due to severe bleeding and difficult access; in these cases, total vascular exclusion was often used.

Transplantation was required when the extensive parenchymal necrosis led to liver failure (15). Associated injuries of other organs were also explored and treated. 


\section{Results}

Out of the 66 pts, 52 pts $(78.8 \%)$ benefitted from surgery and $14 \mathrm{pts}$ (21.2\%) from NOT. The overall major morbidity and mortality rates were $33.3 \%$ (20 pts) and $13.6 \%$ (9 pts), respectively.

Surgery consisted in hepatic resections (HR) in 51 pts (77.3\%) and liver transplantation in one patient (1.5\%). One patient from the liver resection subgroup underwent two consequent hepatic resections; therefore, a total of $52 \mathrm{HR}$ were recorded. Prior perihepatic packing was performed in $39 \mathrm{pts}(76.5 \%)$, while $12 \mathrm{pts}(23.5 \%)$ were hemodynamically unstable. The types of HR are depicted in Table 1. According to our policy, major HR was avoided whenever feasible and was replaced with minor HR (Figs. 1 and 2, Supplemental video, https://www.revistachirurgia.ro/pdfs/?art $=202$ 1-6-678.pdf\&EntryID=922950). The rate of major HR was $51.9 \%$ (27 out of $52 \mathrm{HRs}$ ). Perihepatic packing was previously performed in $38 \mathrm{pts}$ (73.1\%). After surgery, the major complication rate was $35.3 \%$ (18 out of $51 \mathrm{pts})$. The reintervention rate was $11.8 \%$ (6 pts). The major complication rate for major and minor HR were $40.7 \%$ (11 out of 27 pts) and $29.2 \%$ (7 out of $24 \mathrm{pts}$ ), respectively. The mortality rate was $15.7 \%$ (8 pts).

Vascular or biliary reconstructions were performed in 5 pts $(9.8 \%)$ and 6 pts $(11.8 \%)$, respectively. Vascular reconstruction for hepatic artery, portal vein, and hepatic veins was carried out in 1, 2, and 2 patients, respectively. High output bile leaks due to trauma were recorded in $15 \mathrm{pts}(29.4 \%)$ and were treated with anatomic HR (of the territory that was excluded from the biliary tree) in 9 pts $(17.6 \%)$, or with biliary reconstruction with cholangio/hepatico-jejunostomy with a Rouxen-Y loop in 6 pts (11.8\%).

The median operative time was 180 minutes (mean 210; range 140-420). The median blood loss was $800 \mathrm{ml}$ (mean 980; range 500-6500).

The details of the patient that needed liver transplantation were already reported (16).

Patients that benefitted from NOT are presented in Table 2. Major morbidity and
Table 1. Type of hepatic resection (HR) involved in the management of the hepatic injuries (HIs)

\begin{tabular}{lcc}
\hline Type of hepatic resection & No of pts & $\%$ \\
\hline Major resections & 27 & 51.9 \\
\hline Right hemihepatectomy & 19 & 36.5 \\
\hline Left hemihepatectomy & 2 & 3.8 \\
\hline Extended right hemihepatectomy & 4 & 7.7 \\
\hline Extended left hemihepatectomy & 2 & 3.8 \\
\hline Minor resections & 25 & 48.1 \\
\hline Left lateral sectionectomy & 11 & 21.2 \\
\hline Posterior right sectionectomy & 3 & 5.8 \\
\hline Extended posterior right sectionectomy & 1 & 1.9 \\
\hline Extended left lateral sectionectomy & 2 & 3.8 \\
\hline Central LR (non-anatomic) & 2 & 3.8 \\
\hline Limited non-anatomic resection & 6 & 11.5 \\
\hline Anatomic resections & 35 & 67.3 \\
\hline Non-anatomic resections & 17 & 32.7 \\
\hline
\end{tabular}

mortality rates were $14.3 \%$ ( 2 out of $14 \mathrm{pts}$ ) and $7.1 \%$ (1 patient), respectively. The death recorded during NOT was related to associated thoracic trauma.

\section{Discussion}

Liver trauma remains challenging in terms of diagnosis and treatment. To optimize them, the trauma mechanism must be thoroughly evaluated. Blunt hepatic injuries (HI) may be due to crush and/or deceleration. Deceleration determines parenchymal injury along the right portal fissure, while crush determines injury on the central part of the liver, and if there is any compression, it can cause haemorrhage of the segment 1 . The hepatic veins and inferior vena cava may also be injured in these patients. Interestingly, we had a patient

Table 2. The hepatic injuries (HIs) according to the American Association for the Surgery of Trauma (AAST) system and therapy

\begin{tabular}{ccccc}
\hline & \multicolumn{2}{c}{ Surgery } & \multicolumn{2}{c}{ Nonoperative treatment } \\
\hline AAST grade & No of pts & $\%$ & No of pts & $\%$ \\
\hline I & - & - & - & - \\
\hline II & 0 & 0.0 & 1 & 1.5 \\
\hline III & 2 & 3.0 & 9 & 13.6 \\
\hline IV & 21 & 31.8 & 4 & 6.1 \\
\hline V & 29 & 43.9 & 0 & 0.0 \\
\hline VI & - & - & - & - \\
\hline Total & 52 & 78.8 & 14 & 21.2 \\
\hline
\end{tabular}


Figure 1. Enhanced CT-scan for a crushing trauma (landslide) in a 16-year-old male patient, referred from a paediatric hospital for grade $V$ liver laceration with active bleeding from the right hepatic vein (arrow) and large amount of peritoneal fluid. The patient also had kidney contusion with subcapsular and perirenal hematoma, and thoracic contusion.

For further details see the Supplemental Video
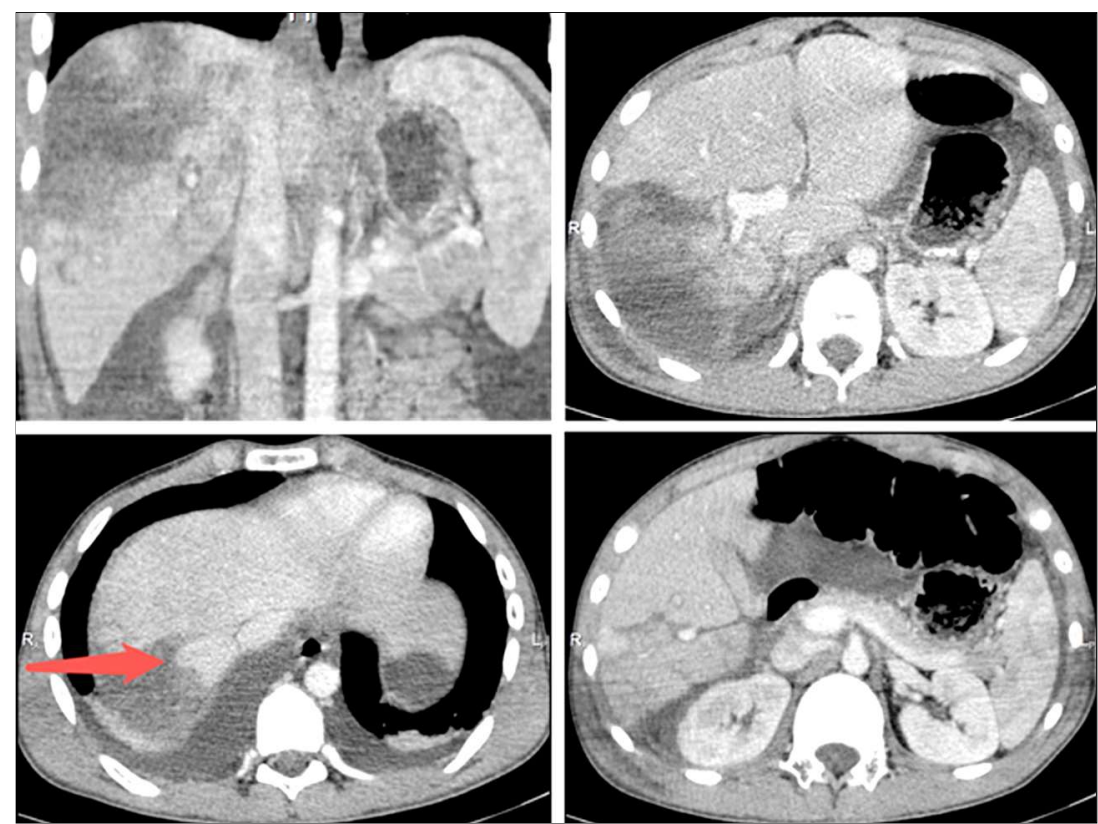

Figure 2. Intraoperative aspects after hepatic resection and the surgical specimen (same patient as in Fig. 1). Even though the patient was stable, he presented with signs of peritonitis that required surgery. Intraoperatively, a massive hemocholeperitoneum was found due to laceration of segments 6 and 7 involving the right hepatic vein, with high-output bile leak and hepatic necrosis of segment 7 . Therefore, nonanatomic ultrasound-guided hepatic resection of segment 7 extended to segment 6 and 1 , along with the right hepatic vein and the rupture bile duct was performed. The postoperative course was uneventful, and the patient was transferred back to the paediatric hospital in the second postoperative day.

For further details see the Supplemental Video
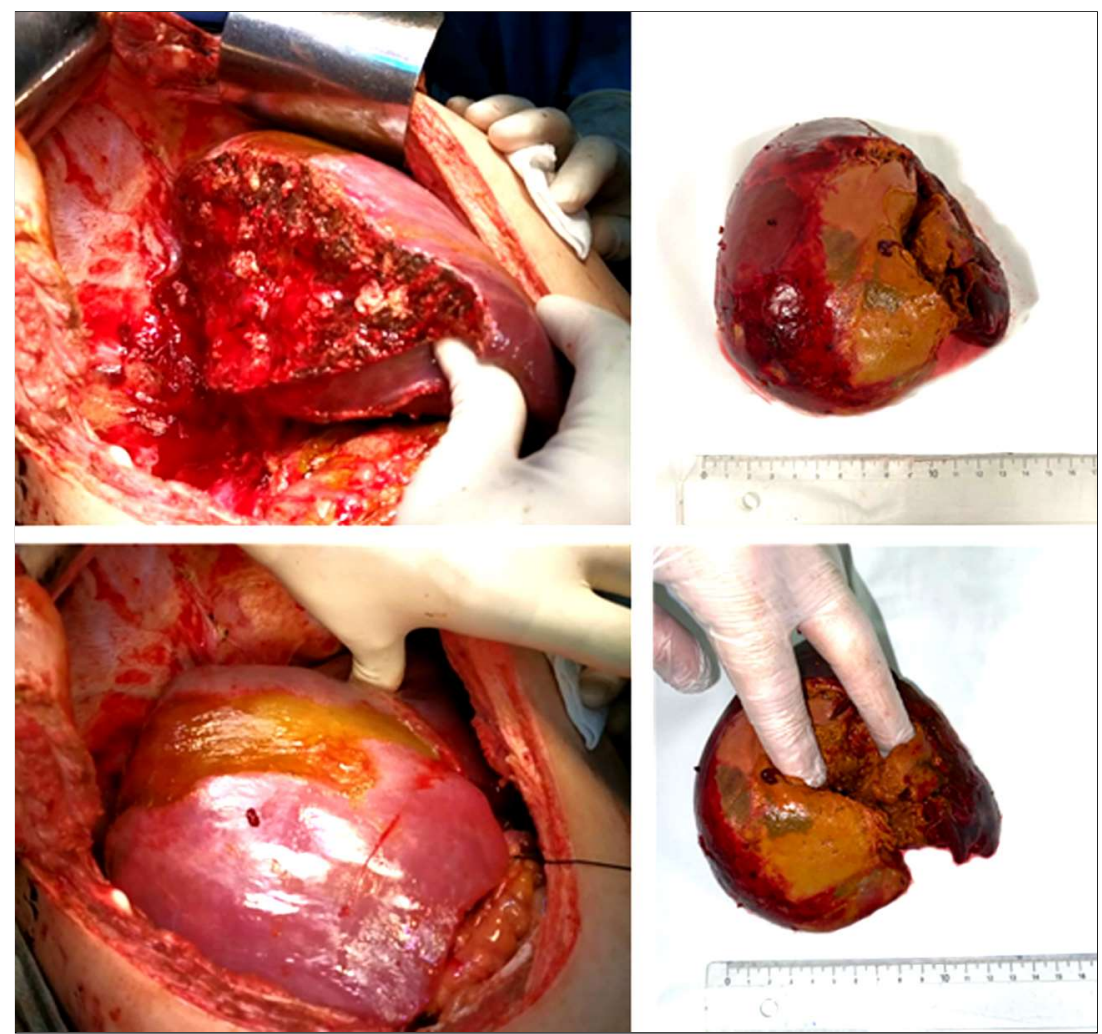

with trauma limited to segment 1 alone, associated with injury of the inferior vena cava and high-output bile leak, who was treated with left hemihepatectomy after failed suture of the injured bile duct of S1.

In case of a hemodynamically stable patient, a rigorous assessment should be carried out, including a comprehensive clinical 
history, physical examination, laboratory and imagistic investigations.

If the patient is unstable, unresponsive to treatment, and/or shows signs of peritonitis, then an emergent laparotomy should be performed.

Contrast-enhanced CT-scan is the investigation of choice when assessing liver trauma, establishing the HI grade according to AAST classification. The active hepatic bleeding is demonstrated by the pooling of contrast material (17). The presence of blood in the Glissonean sheath, appearing as a low density area surrounding the portal triad ("periportal tracking") is frequently associated with biliary injury; if observed in the periphery, it may indicate a bile leak (18).

In stable patients with active arterial bleeding, angiography is the main choice, due to its capacity to perform haemostasis through arterial embolization, avoiding surgery in a significant number of patients $(10,19-22)$. Also in stable patients, MRI is recommended for assessing bile ducts injury (1). However, it is time consuming, making it suboptimal in emergency settings. ERCP can also be used in these situations, being able to treat a bile leak by trans-papillary stenting (23). In case of dubious diagnosis, laparoscopy may provide favourable results.

Non-operative treatment (NOT) is based on the ability of liver to induce spontaneous haemostasis in more than half of patients. The selecting criteria for NOT is based on hemodynamic stability (independently of hemoperitoneum volume), absence of signs of peritonitis, availability of intensive care monitoring, experienced surgeons and immediate access to operating room in case of NOT failure (24-26). However, patients with continued active bleeding and coagulopathy, even if hemodynamically stable during NOT, should be re-evaluated for surgery.

Whenever feasible, NOT should be the first choice in the management of liver trauma. NOT is most effective in HI with low AAST grade (I to III), which are the most frequent HI (up to $67 \%$ of patients) (2). Also, HI with higher AAST grade (IV or V) occurred in a stable patient may benefit from NOT. HI with AAST Grade VI is always referred to urgent surgery, as it presents with haemorrhagic shock. It is also associated with very high mortality, and death usually occurs prior to hospital admission.

NOT is used in over $80 \%$ of blunt HIs, being successful in more than $90 \%$ of these cases (27). When feasible, it provides improved overall survival when compared with surgery, with reduced costs (28). NOT is successful due to the developments in imaging, intensive care monitoring and support, and in interventional treatment (29).

Angioembolization is effective in controlling bleeding in stable patients, and up to $5 \%$ of patients with NOT may require this procedure (30). Furthermore, it may also treat posttraumatic complications, such as pseudoaneurysm, intrahepatic arterio-venous fistula, haemobilia. The success rate may be more than $90 \%$ (14). It can also be used for controlling bleeding after surgery in $12-28 \%$ of patients (30). In our study group, arterial embolization was performed in one case. The low rate of angioembolization may be due to the fact that most liver traumas were high grade HI, with complex vascular and biliary injuries. Percutaneous drainage may be used for treating symptomatic biloma and abscesses (31).

However, complications during NOT may occur. For example, bile leaks may occur in up to $21 \%(21,32-34)$. Also, abscesses can form, requiring fast diagnosis, antibiotic therapy and drainage, but also surgery if these methods fail (35). Moreover, the probability of NOT failure increases with the severity of liver trauma.

Therefore, surgery still plays an important role in treating complex HIs. In unstable patient, emergency surgery is mandatory. In stab wounds, besides the guidelines used for blunt trauma, the topography, angle of entrance and deepness (beyond the peritoneum or not) must be taken into consideration. In gunshot wounds, the standard approach is immediate laparotomy (36); however, some authors advocate for NOT in 
selected hemodynamically stable patients. Nevertheless, this approach is recommended in experienced centers because injuries are frequently not properly diagnosed, leading to complications and death that would have been avoided in case of upfront surgery $(37,38)$. However, NOT is unsuccessful in approximately $33 \%$ of these patients (39-42).

Operative treatment is deployed in around $15-20 \%$ of the cases with liver trauma $(1,2)$. In our experience, the rate was significantly higher $(78.8 \%)$ because of the severity of the treated HI, as most of our patients had AAST high-grade lesions, IV and V grades (81.8\%). Moreover, most of our patients were referred after perihepatic packing (73.1\%). The standard surgical approach is open. Incisions depend on the approach; for example, a midline incision may be initially used, which can be subsequently extended to insure proper liver exposure. Controlling the bleeding should be the first priority (43), while intraoperative exploration of all intrabdominal organs is mandatory to identify all injuries. In case of massive hepatic bleeding, the use of packs is the first choice; if unsuccessful, other methods should be used, such as the vascular control via Pringle maneuver or even total vascular exclusion, and/or direct compression. Intraoperative ultrasound is very useful for assessing both parenchymal and vascular injuries (44).

The current surgical policy is conservative, aiming to avoid parenchymal sacrifice whenever feasible. Moreover, when hepatic resection is needed, efforts should be made to avoid major resections (35). In this sense, direct suture/ligation of the intra-parenchymal bleeding vessel, repair of vessel injury under vascular control (Pringle maneuver or total vascular exclusion). If the vessels are injured beyond repair, then the resection of the corresponding territory is mandatory. However, main hepatic vessel repair and/or complex hepatic resections should be carried out in tertiary HPB centers. When performed in this setting, HR for HI provides low morbidity and mortality rates, of $17-30 \%$ and $2-9 \%$, respectively $(45,46)$. Hepatic sutures should be used with caution, as they may increase the bleeding, induce hematomas and/or ischemia, and cause biliary injury. A good choice for stopping diffuse bleeding is diathermy coagulation, bipolar coagulation, or argon beam coagulator. Use of haemostatic material is recommended (fibrin glue, patches, etc).

When the haemorrhage cannot be controlled, perihepatic packing is the best choice, as it offers time to stabilize the patient and undergo surgery in better conditions (47). Complications after packing can be immediate, such as the inability to control the bleeding, or late, such as infection, sepsis, and multiple system and organ failure (MSOF). After perihepatic packing, definitive surgery should be performed after 24-48 hours (48). However, in our experience, whenever considered useful and in absence of significant inflammatory response, we extended the period to 72 hours without any related complications.

Whenever in unfavourable setting, the strategy of temporary haemostasis, based on perihepatic packing, is always recommended in severe HI, offering the patient the best chance of survival. This allows the definitive surgical treatment to be carried out in a referral HPB center, as scheduled surgery, providing the best chance for cure with reduce complication and mortality rates (49).

Resectional debridement is a common surgical procedure (50). Anatomic liver resections should be performed only when all the other methods failed and cannot be replaced with minor resection. This type of resection is usually indicated in traumatic sectioning of the main liver vessels, such as main portal pedicles and/or hepatic veins (43). Authors report that satisfactory results can be achieved only in tertiary HPB centers (51).

Injuries of the hepatic veins and/or adjacent inferior vena cava may occur in approximately $10 \%$ of the patients with liver trauma (Figs. 1 and 2, Supplemental Video, https://www.revistachirurgia.ro/pdts/?art=202 1-6-678.pdf\&EntryID=922950). These injuries are severe (AAST grade V) and difficult to treat, being associated with very high mortality rate to up to $77 \%(43,52)$. For 
this reason, particular care must be paid during reintervention when removing the packs in vicinity of the hepatocaval confluence and inferior vena cava, as massive bleeding may occur from a venous lesion that was temporary controlled by packing. In our experience, this happened in one patient, who had an unknown large lesion of the left hepatic vein at the hepatocaval confluence, that produced important bleeding after packing removal.

In complex venous injuries with massive bleeding, total vascular exclusion is recommended. If the venous return is to be preserved, a veno-venous or an atriocaval shunt may be used (53). However, it carries a high risk of vital complications (e.g. thrombosis and air embolism) (43). In our experience, vascular or biliary reconstructions were performed in $11.1 \%$ and $13.5 \%$, respectively.

Bile leaks are difficult to diagnose preoperatively and they are usually discovered during surgery. Males are 5 times more exposed to this type of injury than women. The median age of these patient is 30 years, many of these being children (54). In blunt traumas, injuries of the common bile duct are relatively rare (5\%), but usually are associated with severe liver trauma, frequently involving the hepatic artery and/or portal vein (55), with a high risk of intraoperative death due to bleeding (56). Of note, we had in our experience on such patient, with a severe laceration of the right hemiliver associated with the avulsion of the right portal vein and complete transection of the common bile duct, who was referred to our center after periliver packing; surgery consisted in right hepatectomy and Roux-en-Y cholangiojejunostomy (16). Gallbladder injury also frequently occurs in such patients (57). The most common immediate complications after biliary trauma are bile leak and sepsis, with a mortality rate of about $10 \%$ (54). As late complications, some of the patients may develop biliary stenosis.

The most common complications after surgery for liver trauma include re-bleeding, bile leak, intrahepatic arterioportal fistulas, abscesses, liver failure and sepsis.
Haemorrhage can also occur later, through haemobilia (58). High grade HI have high morbidity and mortality rates, depending on the trauma severity, due to haemorrhagic shock, high risk of rebleeding despite surgery, hematoma, biloma, bile leak, liver necrosis, sepsis and MSOF.

The morbidity after liver trauma is dependent on the AAST grade varying from $5 \%$, in case of grade III, to over $50 \%$, in case of grade V $(35,59)$. Consequently, mortality increases in high-grade HIs (IV and V) (60). Following hepatic trauma, the overall mortality rate is $10-15 \%$. Death is usually provoked by bleeding or by septic complications. Blunt HI have higher mortality rate $(10-30 \%)$ when compared to penetrating $\mathrm{HI}(0-10 \%)$.

NOT and perihepatic packing are successful in reducing the mortality rate even in severe $\mathrm{HI}$ $(28,59,61)$. Even more, NOT is successful in many of these cases, leading to low mortality rates that vary between 0 and $8 \%(25,27,30$, $52,62-69)$. In our study, the mortality after NOT was in accordance with the literature (7.1\%). It is worth mentioning that we had few cases with NOT because of the severity of the liver trauma referred to our center, and the fact that most patients arrived after initial surgery performed elsewhere. Moreover, the one death occurred in this subgroup of patients was unrelated to HI. Clearly, the mortality rate is significantly higher in case of high-grade $\mathrm{HI}$ requiring surgery, ranging from 30 to $68 \%$. Importantly, in these cases the mortality was not influenced by initially attempted of NOT (49). Of note, the mortality raises to up to $77 \%$ in case of injury of the liver hilum and/or inferior vena cava (52). In our study, surgery for high-grade HIs had a significantly lower mortality rate $(15.7 \%)$ when compared to the literature. After surgery, complications requiring reinterventions occur in up to $50 \%$ of cases (70). However, in our experience, the reintervention rate was significantly low (11.8\%).

Total hepatectomy followed by liver transplantation may be required in selected patients with liver failure after complex trauma (71). Despite a high retransplantation 
rate, the long-term survival is similar to other benign indications for LT (72). In our study, we had one patient which required transplantation, a 22-year-old female with liver failure after extensive multiple bilobar lacerations (16); the patient is currently alive with no complications at 6 year after transplantation.

Therefore, for best results, we recommend that liver resections, especially major HR and/or vascular and biliary reconstructions, should be performed in a high-volume HPB center, reducing the morbidity and mortality rates, while having the liver transplantation as a salvage solution. With around 4000 liver resections and $1250 \mathrm{LTs}$, our hospital is an established national referral center for liver surgery.

\section{Conclusion}

Hepatic resections, especially major ones and/or involving vascular and biliary reconstructions, as well as non-operative treatment for severe hepatic injuries, are to be carried out in tertiary HPB centers, thus minimizing the morbidity and mortality rates, while having the liver transplantation as salvage option.

\section{Acknowledgements}

This paper is part of $\mathrm{PhD}$ theses, currently under development by Bianca Mitricof, and Alexandru Barcu, PhD students at Medical Doctoral School, IOSUD Titu Maiorescu University of Bucharest.

We thank Anda Georgescu, student at Carol Davila University of Medicine and Pharmacy, Bucharest, for contributing to the literature review.

\section{Conflicts of Interest}

The authors certify that there is no conflict of interest with any financial organization regarding the material discussed in the manuscript

\section{Funding: No funding}

\section{Ethical Statement}

For performing this study ethical approval was obtained.

\section{References}

1. Christmas $A$, Jacobs $D$. Management of hepatic trauma in adults. UpToDate.

2. Tinkoff G, Esposito TJ, Reed J, Kilgo P, Fildes J, Pasquale M, et al. American Association for the Surgery of Trauma Organ Injury Scale I: spleen, liver, and kidney, validation based on the National Trauma Data Bank. J Am Coll Surg. 2008;207(5):646-55.

3. Scollay JM, Beard D, Smith R, McKeown D, Garden OJ, Parks R. Eleven years of liver trauma: the Scottish experience. World J Surg. 2005; 29(6):744-9.

4. Feliciano DV, Mattox KL, Jordan GL, Burch JM, Bitondo CG, Cruse PA. Management of 1000 consecutive cases of hepatic trauma (1979-1984). Ann Surg. 1986;204(4):438-45.

5. Fabian TC, Croce MA, Stanford GG, Payne LW, Mangiante EC, Voeller GR, et al. Factors affecting morbidity following hepatic trauma. A prospective analysis of 482 injuries. Ann Surg. 1991;213(6):540-7; discussion 8.

6. https://transport.ec.europa.eu/news/road-safety-european-commissionrewards-effective-initiatives-and-publishes-2020-figures-road-2021-1118 ro

7. Dindo D, Demartines N, Clavien PA. Classification of surgical complications: a new proposal with evaluation in a cohort of 6336 patients and results of a survey. Ann Surg. 2004;240(2):205-13.

8. Gaarder C, Gaski IA, Nșss PA. Spleen and liver injuries: when to operate? Curr Opin Crit Care. 2017;23(6):520-6.

9. Coccolini F, Catena F, Moore EE, Ivatury R, Biffl W, Peitzman A, et al. WSES classification and guidelines for liver trauma. World J Emerg Surg. 2016;11:50.

10. Badger SA, Barclay R, Campbell P, Mole DJ, Diamond T. Management of liver trauma. World J Surg. 2009;33(12):2522-37.

11. Malhotra AK, Fabian TC, Croce MA, Gavin TJ, Kudsk KA, Minard G, et al. Blunt hepatic injury: a paradigm shift from operative to nonoperative management in the 1990s. Ann Surg. 2000;231(6):804-13.

12. Huang YC, Wu SC, Fu CY, Chen YF, Chen RJ, Hsieh CH, et al. Tomographic findings are not always predictive of failed nonoperative management in blunt hepatic injury. Am J Surg. 2012;203(4):448-53.

13. Søndenaa K, Tasdemir I, Andersen E, Skadberg JE, Søreide JA. Treatment of blunt injury of the spleen: is there a place for mesh wrapping? Eur J Surg. 1994;160(12):669-73.

14. Green CS, Bulger EM, Kwan SW. Outcomes and complications of angioembolization for hepatic trauma: A systematic review of the literature. J Trauma Acute Care Surg. 2016;80(3):529-37.

15. Mitricof B, Brasoveanu V, Hrehoret D, Barcu A, Picu N, Flutur E, et al. Surgical treatment for severe liver injuries: a single-center experience. Minerva Chir. 2020;75(2):92-103.

16. Fang JF, Chen RJ, Wong YC, Lin BC, Hsu YB, Kao JL, et al. Pooling of contrast material on computed tomography mandates aggressive management of blunt hepatic injury. Am J Surg. 1998;176(4):315-9.

17. Yokota J, Sugimoto T. Clinical significance of periportal tracking on computed tomographic scan in patients with blunt liver trauma. Am J Surg. 1994;168(3):247-50.

18. David Richardson J, Franklin GA, Lukan JK, Carrillo EH, Spain DA, Miller FB, et al. Evolution in the management of hepatic trauma: a 25-year perspective. Ann Surg. 2000;232(3):324-30.

19. Hoffer EK, Borsa JJ, Bloch RD, Fontaine AB. Endovascular techniques in the damage control setting. Radiographics. 1999;19(5):1340-8.

20. Asensio JA, Demetriades D, Chahwan S, Gomez H, Hanpeter D, Velmahos $G$, et al. Approach to the management of complex hepatic injuries. J Trauma. 2000;48(1):66-9.

21. Misselbeck TS, Teicher EJ, Cipolle MD, Pasquale MD, Shah KT, Dangleben $\mathrm{DA}$, et al. Hepatic angioembolization in trauma patients: indications and 
complications. J Trauma. 2009;67(4):769-73.

22. Carrillo EH, Spain DA, Wohltmann CD, Schmieg RE, Boaz PW, Miller FB, et al. Interventional techniques are useful adjuncts in nonoperative management of hepatic injuries. J Trauma. 1999;46(4):619-22; discussion 22-4

23. Meyer AA, Crass RA, Lim RC, Jeffrey RB, Federle MP, Trunkey DD. Selective nonoperative management of blunt liver injury using computed tomography. Arch Surg. 1985;120(5):550-4.

24. Boone DC, Federle M, Billiar TR, Udekwu AO, Peitzman AB. Evolution of management of major hepatic trauma: identification of patterns of injury. J Trauma. 1995;39(2):344-50

25. Sherman HF, Savage BA, Jones LM, Barrette RR, Latenser BA, Varcelotti JR, et al Nonoperative management of blunt hepatic injuries: safe at any grade? J Trauma. 1994;37(4):616-21.

26. Petrowsky H, Raeder S, Zuercher L, Platz A, Simmen HP, Puhan MA, et al. A quarter century experience in liver trauma: a plea for early computed tomography and conservative management for all hemodynamically stable patients. World J Surg. 2012;36(2):247-54

27. Pachter HL, Feliciano DV. Complex hepatic injuries. Surg Clin North Am 1996;76(4):763-82

28. Shrestha B, Holcomb JB, Camp EA, Del Junco DJ, Cotton BA, Albarado R, et al. Damage-control resuscitation increases successful nonoperative management rates and survival after severe blunt liver injury. J Trauma Acute Care Surg. 2015;78(2):336-41.

29. Melloul E, Denys A, Demartines N. Management of severe blunt hepatic injury in the era of computed tomography and transarterial embolization: A systematic review and critical appraisal of the literature. J Trauma Acute Care Surg 2015;79(3):468-74

30. Goffette PP, Laterre PF. Traumatic injuries: imaging and intervention in post-traumatic complications (delayed intervention). Eur Radiol. 2002 12(5):994-1021

31. Singh V, Narasimhan KL, Verma GR, Singh G. Endoscopic management of traumatic hepatobiliary injuries. J Gastroenterol Hepatol. 2007;22(8):1205-9.

32. Wahl WL, Brandt MM, Hemmila MR, Arbabi S. Diagnosis and management of bile leaks after blunt liver injury. Surgery. 2005;138(4):742-7; discussion 7-8,

33. Hommes M, Nicol AJ, Navsaria PH, Reinders Folmer E, Edu S, Krige JE. Management of biliary complications in 412 patients with liver injuries. J Trauma Acute Care Surg. 2014;77(3):448-51.

34. Kozar RA, Moore JB, Niles SE, Holcomb JB, Moore EE, Cothren CC, et al. Complications of nonoperative management of high-grade blunt hepatic injuries. J Trauma. 2005;59(5):1066-71.

35. Cogbill TH, Moore EE, Jurkovich GJ, Feliciano DV, Morris JA, Mucha P. Severe hepatic trauma: a multi-center experience with 1,335 liver injuries. J Trauma. 1988:28(10):1433-8

36. Omoshoro-Jones JA, Nicol AJ, Navsaria PH, Zellweger R, Krige JE, Kahn DH Selective non-operative management of liver gunshot injuries. Br J Surg. 2005:92(7):890-5.

37. Demetriades D, Hadjizacharia P, Constantinou C, Brown C, Inaba K, Rhee P, et al. Selective nonoperative management of penetrating abdominal solid organ injuries. Ann Surg. 2006;244(4):620-8.

38. Jurkovich GJ. Selective non-operative management in 25737 patients with penetrating abdominal injuries (Br J Surg 2011; 99(Suppl 1): 157-167). Br J Surg 2012;99 Suppl 1:164-5

39. Zafar SN, Nabeel Zafar S, Rushing A, Haut ER, Kisat MT, Villegas CV, et al. Outcome of selective non-operative management of penetrating abdominal injuries from the North American National Trauma Database. Br J Surg. 2012;99 Suppl 1:155-64

40. Richardson JD. Changes in the management of injuries to the liver and spleen. $J$ Am Coll Surg. 2005;200(5):648-69.

41. Demetriades D, Gomez H, Chahwan S, Charalambides K, Velmahos G, Murray J et al. Gunshot injuries to the liver: the role of selective nonoperative management. J Am Coll Surg. 1999;188(4):343-8.

42. Jacobs D, Christmas A. Surgical techniques for managing hepatic injury. UpToDate.

43. Polanco P, Leon S, Pineda J, Puyana JC, Ochoa JB, Alarcon L, et al. Hepatic resection in the management of complex injury to the liver. J Trauma. 2008;65(6):1264-9; discussion 9-70

44. Li Petri S, Gruttadauria S, Pagano D, Echeverri GJ, Di Francesco F, Cintorino D, et al. Surgical management of complex liver trauma: a single liver transplant center experience. Am Surg. 2012;78(1):20-5.
45. Calne RY, McMaster P, Pentlow BD. The treatment of major liver trauma by primary packing with transfer of the patient for definitive treatment. Br J Surg. 1979;66(5):338-9.

46. Nicol AJ, Hommes M, Primrose R, Navsaria PH, Krige JE. Packing for control of hemorrhage in major liver trauma. World J Surg. 2007:31(3):569-74

47. Birkmeyer JD, Siewers AE, Finlayson EV, Stukel TA, Lucas FL, Batista I, et al. Hospital volume and surgical mortality in the United States. N Engl J Med. 2002;346(15):1128-37.

48. Cox EF, Flancbaum L, Dauterive AH, Paulson RL. Blunt trauma to the liver Analysis of management and mortality in 323 consecutive patients. Ann Surg. 1988;207(2):126-34.

49. Strong RW, Lynch SV, Wall DR, Liu CL. Anatomic resection for severe liver trauma. Surgery. 1998;123(3):251-7.

50. Piper GL, Peitzman AB. Current management of hepatic trauma. Surg Clin North Am. 2010;90(4):775-85

51. Chen RJ, Fang JF, Lin BC, Jeng LB, Chen MF. Surgical management of juxtahepatic venous injuries in blunt hepatic trauma. J Trauma. 1995; 38(6):88690

52. Kitahama A, Elliott LF, Overby JL, Webb WR. The extrahepatic biliary tract injury: perspective in diagnosis and treatment. Ann Surg. 1982;196(5):536-40.

53. Burgess P, Fulton RL. Gallbladder and extrahepatic biliary duct injury following abdominal trauma. Injury. 1992;23(6):413-4.

54. Dawson DL, Johansen KH, Jurkovich GJ. Injuries to the portal triad. Am J Surg 1991:161(5):545-51.

55. PENN I. Injuries of the gall-bladder. Br J Surg. 1962;49:636-41.

56. Forlee MV, Krige JE, Welman CJ, Beningfield SJ. Haemobilia after penetrating and blunt liver injury: treatment with selective hepatic artery embolisation. Injury. 2004;35(1):23-8

57. Kozar RA, Moore FA, Cothren CC, Moore EE, Sena M, Bulger EM, et al. Risk factors for hepatic morbidity following nonoperative management: multi-center study. Arch Surg. 2006;141(5):451-8; discussion 8-9.

58. Schweizer W, Tanner S, Baer HU, Lerut J, Huber A, Gertsch P, et al. Management of traumatic liver injuries. Br J Surg. 1993:80(1):86-8.

59. Peitzman AB, Richardson JD. Surgical treatment of injuries to the solid abdominal organs: a 50-year perspective from the Journal of Trauma. J Trauma. 2010;69(5):1011-21.

60. Croce MA, Fabian TC, Menke PG, Waddle-Smith L, Minard G, Kudsk KA, et al. Nonoperative management of blunt hepatic trauma is the treatment of choice for hemodynamically stable patients. Results of a prospective trial. Ann Surg. 1995;221(6):744-53; discussion 53-5

61. Hurtuk M. Reed RL, Esposito TJ, Davis KA, Luchette FA. Trauma surgeons practice what they preach: The NTDB story on solid organ injury management. J Trauma. 2006;61(2):243-54; discussion 54-5.

62. Pachter HL, Knudson MM, Esrig B, Ross S, Hoyt D, Cogbill T, et al. Status of nonoperative management of blunt hepatic injuries in 1995: a multicenter experience with 404 patients. J Trauma. 1996:40(1):31-8.

63. Boese CK, Hackl M, Müller LP, Ruchholtz S, Frink M, Lechler P. Nonoperative management of blunt hepatic trauma: A systematic review. J Trauma Acute Care Surg. 2015;79(4):654-60

64. Letoublon C, Chen Y, Arvieux C, Voirin D, Morra I, Broux C, et al. Delayed celiotomy or laparoscopy as part of the nonoperative management of blunt hepatic trauma. World J Surg. 2008;32(6):1189-93

65. Leppäniemi AK, Mentula PJ, Streng MH, Koivikko MP. Handolin LE Severe hepatic trauma: nonoperative management, definitive repair, or damage control surgery? World J Surg. 2011;35(12):2643-9.

66. Kozar RA, McNutt MK. Management of adult blunt hepatic trauma. Curr Opin Crit Care. 2010;16(6):596-601.

67. Polanco PM, Brown JB, Puyana JC, Billiar TR, Peitzman AB, Sperry JL. The swinging pendulum: a national perspective of nonoperative management in severe blunt liver injury. J Trauma Acute Care Surg. 2013;75(4):590-5

68. Demetriades D, Karaiskakis M, Alo K, Velmahos G, Murray J, Asensio J. Role of postoperative computed tomography in patients with severe liver injury. $\mathrm{Br} J$ Surg. 2003;90(11):1398-400.

69. Heuer M, Kaiser GM, Lendemans S, Vernadakis S, Treckmann JW, Paul A. Transplantation after blunt trauma to the liver: a valuable option or just a "waste of organs"? Eur J Med Res. 2010;15(4):169-73.

70. Kaltenborn A, Reichert B, Bourg CM, Becker T, Lehner F, Klempnauer J, et al. Long-term outcome analysis of liver transplantation for severe hepatic trauma. J Trauma Acute Care Surg. 2013;75(5):864-9. 